\title{
How is the land use-cover changing in drinking water catchments in the coastal range of south-central Chile $\left(35^{\circ}-38.5^{\circ} \mathrm{S}\right)$ ?
}

\author{
¿Cómo está cambiando la cobertura del uso del suelo en las cuencas \\ proveedoras de agua potable de la zona costera del centro-sur de Chile $\left(35^{\circ}-38,5^{\circ} \mathrm{S}\right)$ ?
}

\author{
Jorge León-Muñoz a*, Cristian Echeverría ${ }^{\text {b }}$, Rodrigo Fuentes ${ }^{\text {b }}$, Felipe Aburto o ${ }^{\text {b }}$ \\ *Corresponding author: a Traful consultores SpA, Concepción, Chile, jorgeleon@trafulconsultores.cl \\ b Universidad de Concepción, Facultad de Ciencias Forestales, Victoria 631, Concepción, Chile
}

\begin{abstract}
SUMMARY
Different studies on land use-cover change (LUCC) have revealed substantial loss of native forests in south-central Chile in the last decades. However, little information exists about LUCC in drinking water catchments (DWC) affected by water scarcity. We analyzed the LUCC in 25 catchments that supply water to urban and rural communities in the coastal range of south-central Chile, between 1986 and 2011. Results showed that 21 DWC exhibited an increase in intensity of land uses, from native forest and shrublands to forest plantations of exotic species. A higher rate of deforestation was observed in unprotected catchments $\left(2.7 \% \pm 1.5\right.$ year $\left.r^{-1}\right)$ than in catchments protected by the State $\left(0.5 \% \pm 0.4\right.$ year $\left.^{-1}\right)$. Our spatio-temporal assessment of LUCC at the catchment scale reveals the high degree of pressure in land condition in critical DWC. It is urgent to develop a landscape planning strategy to conserve drinking water source areas in changing landscapes.
\end{abstract}

Key words: water supply, land use-cover, native forest, forest plantations.

\section{RESUMEN}

Durante las últimas décadas numerosos estudios sobre cambio de cobertura y uso de suelo (CCUS) han reportado una significativa pérdida de bosque nativo en la zona centro sur de Chile. A pesar de esto, existe poca información sobre el CCUS en cuencas abastecedoras de agua para consumo humano emplazadas en zonas de escasez hídrica. Fue analizado el CCUS acontecido entre los años 1986 y 2011 en 25 cuencas proveedoras de agua a comunidades rurales y urbanas de la zona costera del centro sur de Chile. Los resultados evidenciaron un fuerte CCUS en 21 de las cuencas analizadas, con una marcada trayectoria de cambio desde bosque nativo y matorrales a plantaciones forestales de especies exóticas. En este contexto, se registró una alta tasa anual de deforestación en aquellas cuencas que no se encuentran oficialmente protegidas $\left(2,7 \% \pm 1,5 \mathrm{año}^{-1}\right)$, caso contrario al observado en cuencas emplazadas dentro del Sistema Nacional de Áreas Silvestres Protegidas del Estado (SNASPE) (0,5 \% \pm 0,4 año-1). Así, la evaluación espacio-temporal del CCUS reveló la existencia de un alto grado de presión sobre áreas críticas para el abastecimiento de agua para consumo humano, siendo urgente impulsar estrategias de planificación para la conservación de cuencas críticas inmersas en un paisaje cambiante.

Palabras clave: provisión de agua, cobertura y uso de suelo, bosque nativo, plantaciones forestales.

\section{INTRODUCTION}

The United Nations established access to drinking water as a fundamental human right in 2010 (UN 2010). However, changes in socioeconomic, political, and cultural driving forces and climatic conditions are causing a substantial imbalance between water availability and demand (Alcamo et al. 2007). In Chile, the National Strategy for Water Resources (2012-2025) considers water a unique, scarce and strategic resource essential for human life and the preservation of the environment (MOP 2013). Despite this, current efforts in water resource management in Chile have been concentrated on the design and operation of infrastructure such as dams and reservoirs (MOP 2013) though not on understanding the attributes of catchments that support water supply.

It is widely recognized that land use-cover (LUC) is an important attribute of a catchment (Brown et al. 2005, Huber et al. 2010). A clear understanding of the influence of the LUC is key in identifying the probable impacts that it may have on water supply (NSW 2010). Research conducted on catchments in south-central Chile has identified a strong relationship between runoff and forest cover types (Lara et al. 2009). Catchments dominated by wellconserved native forests tend to maximize and ensure high standards of water supply (Nuñez et al. 2006). Accordin- 
gly, some countries have promoted public policies on LUC compatibility in public drinking water source areas (NSW 2010). Changes in LUC have the potential to increase the pressure on water balance (Iroumé and Palacios 2013), especially in areas where water scarcity has not been solved.

The coastal range of south-central Chile has been associated with recurrent summer-autumn water shortages (MOP 2016). Additionally, intense land use-cover change (LUCC) associated with loss in native forest cover over the last decades has been reported in this part of Chile (Echeverría et al. 2006). Despite the need to ensure water supply in this part of the country, there is no clear understanding of the current trend in LUCC in drinking water catchments (DWC) in a landscape seriously affected by human pressures.

In this note, we analyzed the LUCC (rates, trajectories and spatial patterns) in catchments that supply water to urban and rural communities in the coastal range of southcentral Chile $\left(35^{\circ}-38.5^{\circ} \mathrm{S}\right)$. This assessment of LUCC at the catchment scale will inform about the pressures cu- rrently affecting critical DWC embedded in an intensely transformed landscape. We hypothesize that DWC exhibit a lower proportion of natural forest than other uses as a result of a historical shift from native forest and shrublands towards more intensive human-related land uses, being this shift higher in magnitude in unprotected catchments.

\section{METHODS}

Study area. We assessed 25 catchments $\left(1.5\right.$ - $\left.96.7 \mathrm{~km}^{2}\right)$ that provide drinking water to urban (22) and rural communities (3) in the coastal range of south-central Chile $\left(35^{\circ}-38.5^{\circ} \mathrm{S}\right)$. The water withdrawal points, granted for surface water rights by the Chilean General Direction of Waters (DGA), were used for the delimitations of the study catchments. Four of these catchments are located within the Nonguén National Reserve, a protected unit owned by the State's National System of Protected Areas (SNASPE) while the rest of the catchments are not officially protected (figure 1). The annual precipitation in the area ranges bet-
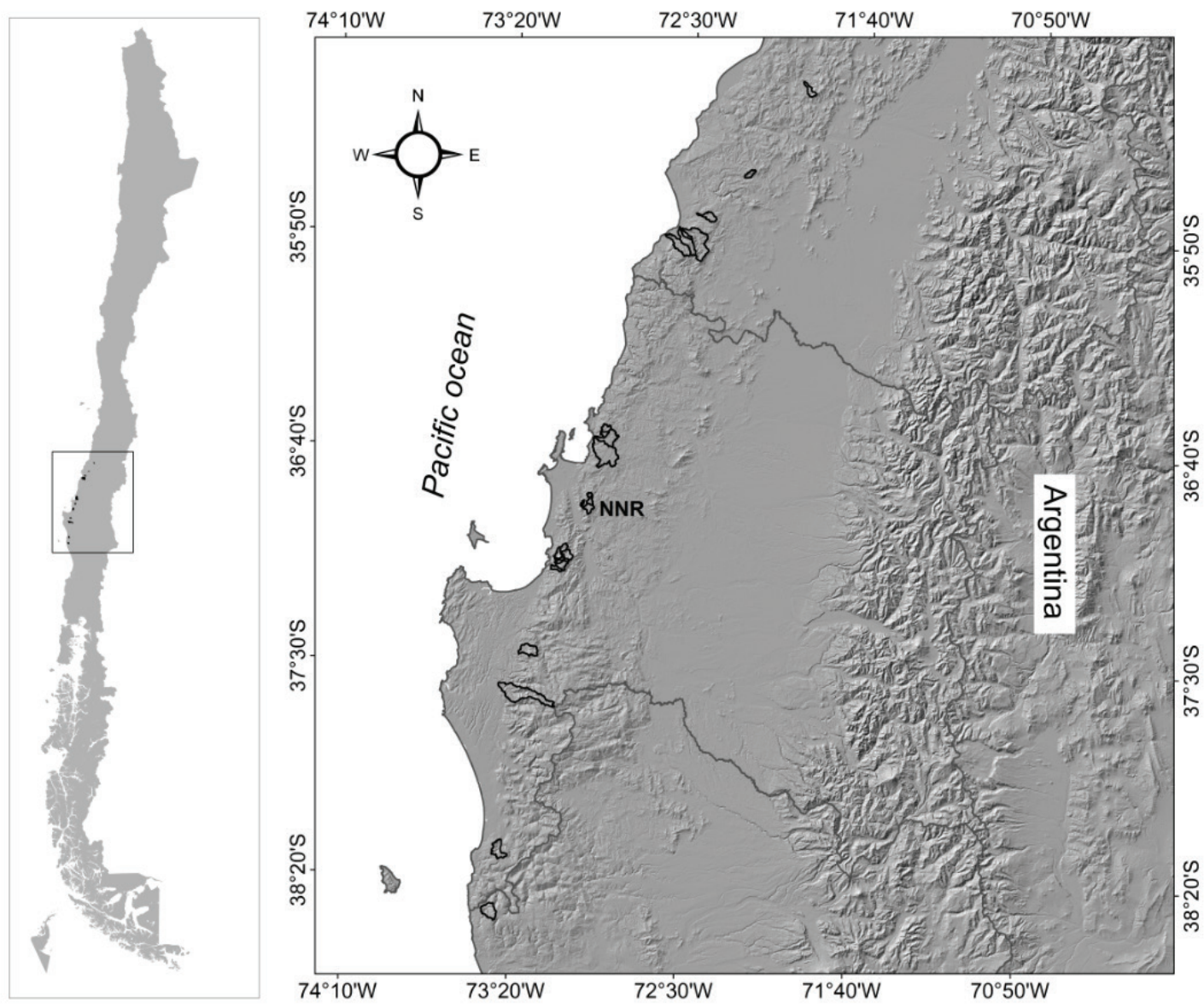

Figure 1. Drinking water catchments analyzed in the coastal range of south-central Chile $\left(35^{\circ}-38.5^{\circ} \mathrm{S}\right)$. NNR shows the catchments located within the National System of Protected Forest Areas (Nonguén National Reserve).

Cuencas proveedoras de agua para consumo humano estudiadas en la zona costera del centro sur de Chile. La sigla NNR identifica las cuencas emplazadas dentro del Sistema Nacional de Áreas Silvestres Protegidas del Estado (Reserva Nacional Nonguén). 
ween 890 and $1120 \mathrm{~mm}$ year $^{-1}$, and the mean temperature varies from 10.7 to $13.5^{\circ} \mathrm{C}$. The fragmentation and conversion of native forests have led to the creation of mosaics where native forests coexist with shrublands, agricultural and pasturelands and forest plantations of exotic species, as well as invasive species (Echeverría et al. 2006).

Land use-cover change. Delimitations of the study catchments were conducted using ArcGIS 10.2 software (ArcHydroTools) and a digital elevation model (DEM) generated at a 30-m spatial resolution (Shuttle Radar Topography Mission SRTM, ASTER GDEM). Catchment delimitation was validated using spatial data generated by the General Water Directorate of Chile and field-based verification points.

In the study catchments, we analyzed the spatial arrangement of LUC types, based on Landsat satellite scenes (Path 233, Row 088) acquired for the years 1986 and 2011. Scene selection considered the total cover of the study area, cloudiness levels, and the summer season. The selected images were corrected geometrically, radiometrically and topographically. The ENVI program 4.5 was hence used with maximum likelihood and training points to classify the images based on field training points ( 880 points for 1986 and 615 points for 2011) and validation points for the accuracy assessment using aerial photography and Google earth imagery for areas of difficult access (409 points for 1986 and 536 points for 2011). The types of LUC were defined based on the National Vegetation Resources Mapping categories (CONAF et al. 1999). The following LUC were used: native forest, forest plantation of exotic species (forest plantations, invasive species), shrublands, agricultural and pasturelands, bare soil and water. The native forest cover considered old growth and secondary forests.

Changes in LUC between 1986 and 2011 were analyzed using IDRISI Land Change Modeler (Clark 2006). We identified major trajectories of LUCC and their contributions to these changes. In addition, the rate of deforestation of native forests was estimated (Echeverría et al. 2007a) and spatial patterns of all LUC types were analyzed using FRAGSTAT 3.3 software (McGarigal et al. 2002). Since the variables were not normally distributed, a nonparametric Wilcoxon signed rank test was used to determine if the LUCC between time intervals were significantly different $(P<0.05)$. The analysis was performed using the statistical software SPSS version 19.0.

\section{RESULTS}

We obtained a global accuracy of $86.4 \%$ for the 1986 scene and $88.7 \%$ for the 2011 scene (table 1 ). The highest precision was obtained by forest plantations (1986: $91.2 \%$ and 2011: $96.6 \%$ ), followed by agriculture and pastureland (1986: $87.5 \%$ and 2011: $92.4 \%$ ). The lowest accuracy was obtained by shrublands in 1986 (76.7 \%) because this LUC showed a spectrum very similar to that shown by young forest plantations (table 1).

The spatial and temporal patterns of LUCC showed that most of the study catchments exhibited a substantial increase in the area covered by forest plantations in 2011 (figures 2 and 3). These areas covered by forest plantation were previously occupied by native forest and shrublands in 1986 (figures 2 and 3). These patterns of LUCC were also observed in the buffer area of the study catchments (figure 4). In 24 of the 25 study catchments, we found loss of native forest at a mean annual rate of $2.4 \% \pm 1.6$, with values higher than $2.5 \%$ in more than half of the catchments (figure 3). The total native forest area significantly declined from $27.4 \%$ to $19.2 \%$ for all the catchments (Z: -4.211 $P<0.001)$. Similarly, shrublands significantly decreased from $14.5 \%$ in 1986 to $8.15 \%$ in 2011 (Z: -3.673 $P<0.001)$. Conversely, the areas covered by forest plantations significantly increased $(Z:-4.372 P<0.001)$ from $53.8 \%$ in 1986 to $70 \%$ in 2011 in the 25 catchments. Most of the catchments presented an increase in forest plantation higher than $30 \%$ (figure 3). Agricultural land did not present significant changes $(P<0.775)$.

The unprotected catchments exhibited a substantial replacement of native forest by forest plantation (figure 3). In 1986, 13 catchments were mainly covered (> $50 \%$ of the area) by forest plantation; in 2011, as many as 20 catchments were dominated by this land use. Conversely, in 1986, native forest was the prevailing land cover in seven catchments; in 2011, only four catchments presented native forest as the main land cover. These four catchments were located in the SNASPE (figure 3).

The landscape metrics showed a tendency toward the formation of a mosaic dominated by human-related land uses in unprotected catchments (figures 3 and 5). In these catchments, the largest patch index of native forest declined sharply from 1986 until 2011, representing by the end of this period less than $1 \%$. The juxtaposition index for these unprotected catchments increased between 1986 and 2011. Conversely, the protected catchments showed a low adjacency between patches of native forest and anthropic land uses in both study years (figure 5).

\section{DISCUSSION}

Worldwide, there is growing concern regarding water security (Alcamo et al. 2007). In Europe, approximately $50 \%$ of catchments will present water scarcity by 2030 (EC 2012). This scenario has been primarily related to variations in magnitude and distribution of rainfall (droughts and extreme events), and LUCC among other variables (Sun et al. 2008). Our results reveal that in the coastal range of south-central Chile $\left(35^{\circ}-38.5^{\circ} \mathrm{S}\right)$ DWC are also exhibiting an increase of human-related land uses with significant loss of native forest and shrublands. Additionally, the catchments show an increase in the area of forest plantations from 1986 to 2011, becoming the dominant 
Table 1. Confusion matrices of 1986 and 2011 Landsat scenes. NF: native forests; FP: forest plantation of exotic species; SHR: shrublands; APL: Agricultural and pasturelands; UA: urban areas.

Matrices de confusión para las escenas Landsat de los años 1986 y 2011. NF: bosque nativo; FP: plantaciones forestales exóticas; SHR: matorrales; APL: agricultura y praderas; UA: áreas urbanas.

\begin{tabular}{|c|c|c|c|c|c|c|c|c|c|}
\hline \multirow{2}{*}{ Image } & \multirow{2}{*}{ Classified data } & \multicolumn{6}{|c|}{ Reference data (number of points) } & \multirow{2}{*}{$\begin{array}{c}\text { Error } \\
\text { commission } \\
(\%)\end{array}$} & \multirow{2}{*}{$\begin{array}{c}\text { User } \\
\text { accuracy } \\
(\%)\end{array}$} \\
\hline & & $\mathrm{NF}$ & FP & SHR & APL & UA & Total & & \\
\hline \multirow{9}{*}{1986} & NF & 74 & 9 & 5 & 0 & 0 & 88 & 15.9 & 84.1 \\
\hline & FP & 7 & 93 & 2 & 0 & 0 & 102 & 8.8 & 91.2 \\
\hline & SHR & 2 & 10 & 59 & 0 & 0 & 71 & 16.9 & 83.1 \\
\hline & APL & 0 & 0 & 11 & 119 & 6 & 136 & 12.5 & 87.5 \\
\hline & UA & 0 & 0 & 0 & 12 & 63 & 75 & 16.0 & 84.0 \\
\hline & Total & 83 & 112 & 77 & 131 & 69 & 409 & & \\
\hline & Error omission (\%) & 10.8 & 17.0 & 23.4 & 9.2 & 8.7 & & & \\
\hline & Producer’s accuracy (\%) & 89.2 & 83.0 & 76.6 & 90.8 & 91.3 & & & \\
\hline & \multicolumn{9}{|c|}{ Overall classification accuracy: $86,4 \%$} \\
\hline \multirow{9}{*}{2011} & NF & 95 & 20 & 5 & 0 & 0 & 120 & 20.8 & 79.2 \\
\hline & FP & 5 & 170 & 1 & 0 & 0 & 176 & 3.4 & 96.6 \\
\hline & SHR & 5 & 16 & 69 & 0 & 0 & 90 & 23.3 & 76.7 \\
\hline & APL & 0 & 0 & 8 & 127 & 3 & 138 & 8.0 & 92.0 \\
\hline & UA & 0 & 0 & 0 & 5 & 75 & 80 & 6.3 & 93.8 \\
\hline & Total & 105 & 206 & 83 & 132 & 78 & 536 & & \\
\hline & Error omission (\%) & 9.5 & 17.5 & 16.9 & 3.8 & 3.8 & & & \\
\hline & Producer’s accuracy (\%) & 90.5 & 82.5 & 83.1 & 96.2 & 96.2 & & & \\
\hline & Overall classification accl &, $7 \%$ & & & & & & & \\
\hline
\end{tabular}

1986

2011

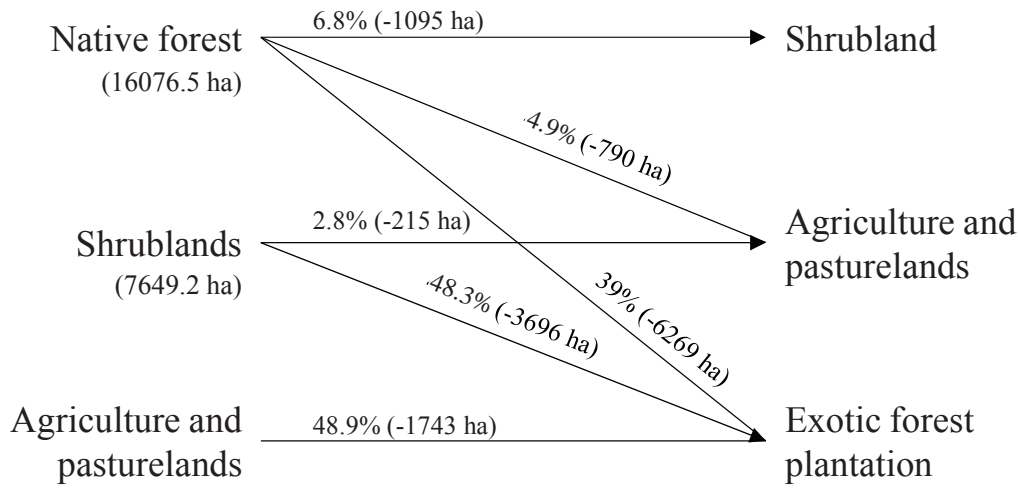

(3565.4 ha)

Figure 2. Major change trajectories and their contributions to the net change of the respective land use-cover type in 1986.

Principales trayectorias de cambio y sus contribuciones a la variación neta del respectivo tipo de cobertura y uso de suelo del año 1986. 

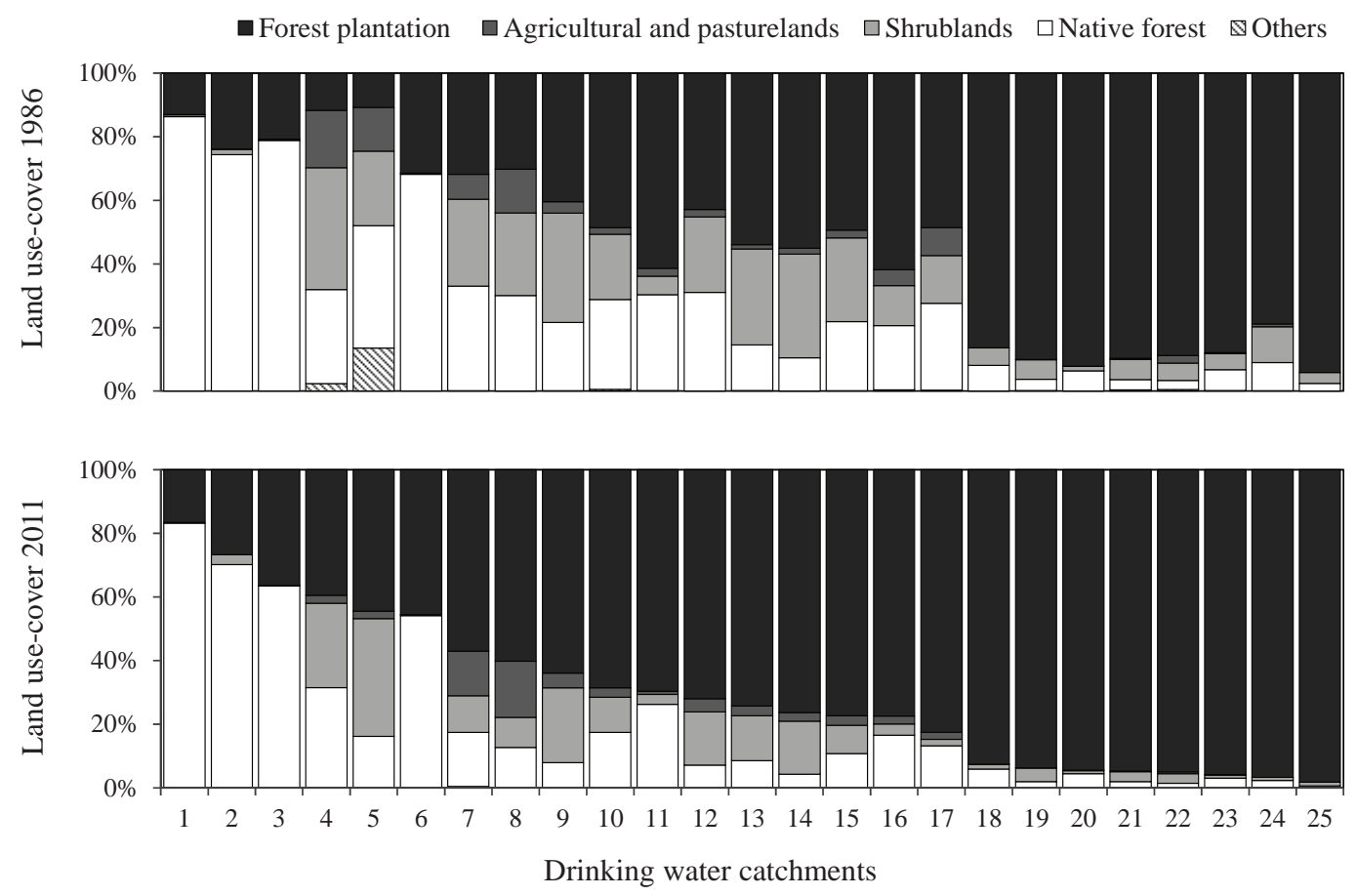

Figure 3. Land cover change (1986 and 2011) for 25 drinking water catchments in the coastal range of south-central Chile. The class "Others" corresponds to bare soil and water bodies. The catchments numbers 1, 2, 3 and 6 are located within the National System of Protected Forest Areas. Catchments are arranged according to the increase of anthropic land uses (forest plantation of exotic species plus agricultural and pastureland).

Cambio de cobertura de suelo (años 1986 y 2011) en 25 cuencas proveedoras de agua para consumo humano ubicadas en la zona costera del centro sur de Chile. La clase Otros contiene las superficies de suelo descubierto y cuerpos de agua. Las cuencas número 1, 2, 3 y 6 se emplazan dentro del Sistema Nacional de Áreas Silvestres Protegidas del Estado. Las cuencas se encentran ordenadas respecto al incremento de usos de suelo antrópicos (plantaciones forestales de especies exóticas más superficies agropecuarias).

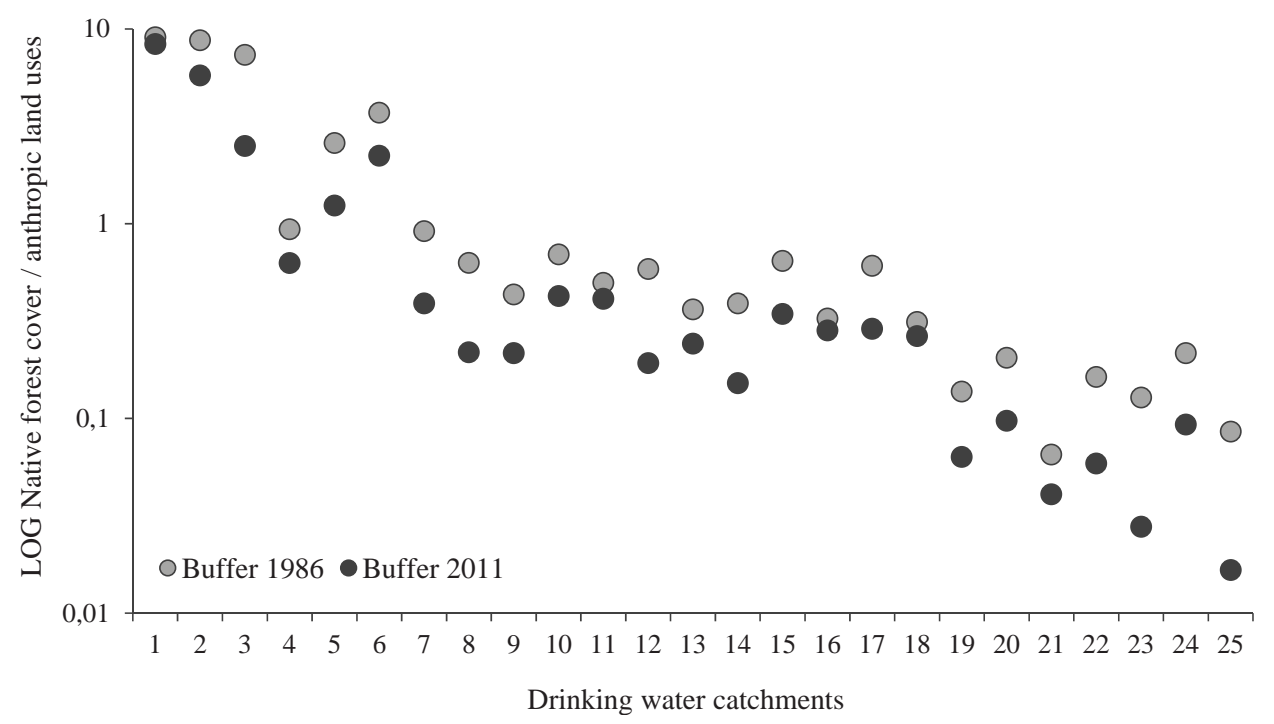

Figure 4. Ratio between native forest cover and anthropic land uses (forest plantation of exotic species plus agricultural land) at the buffer-stream scale $(90 \mathrm{~m})$. The catchments numbers 1, 2, 3 and 6 are located within the National System of Protected Forest Areas. Catchments are arranged according to the increase of anthropic land uses (see figure 3).

Relación entre las coberturas de bosque nativo y usos antrópicos (plantaciones forestales exóticas y superficies agropecuarias) a escala de las zonas riparianas $(90 \mathrm{~m}$ ). Las cuencas números 1, 2, 3 y 6 se emplazan dentro del Sistema Nacional de Áreas Silvestres Protegidas del Estado. Las cuencas se encuentran ordenadas respecto al incremento de usos de suelo antrópicos (ver figura 3). 


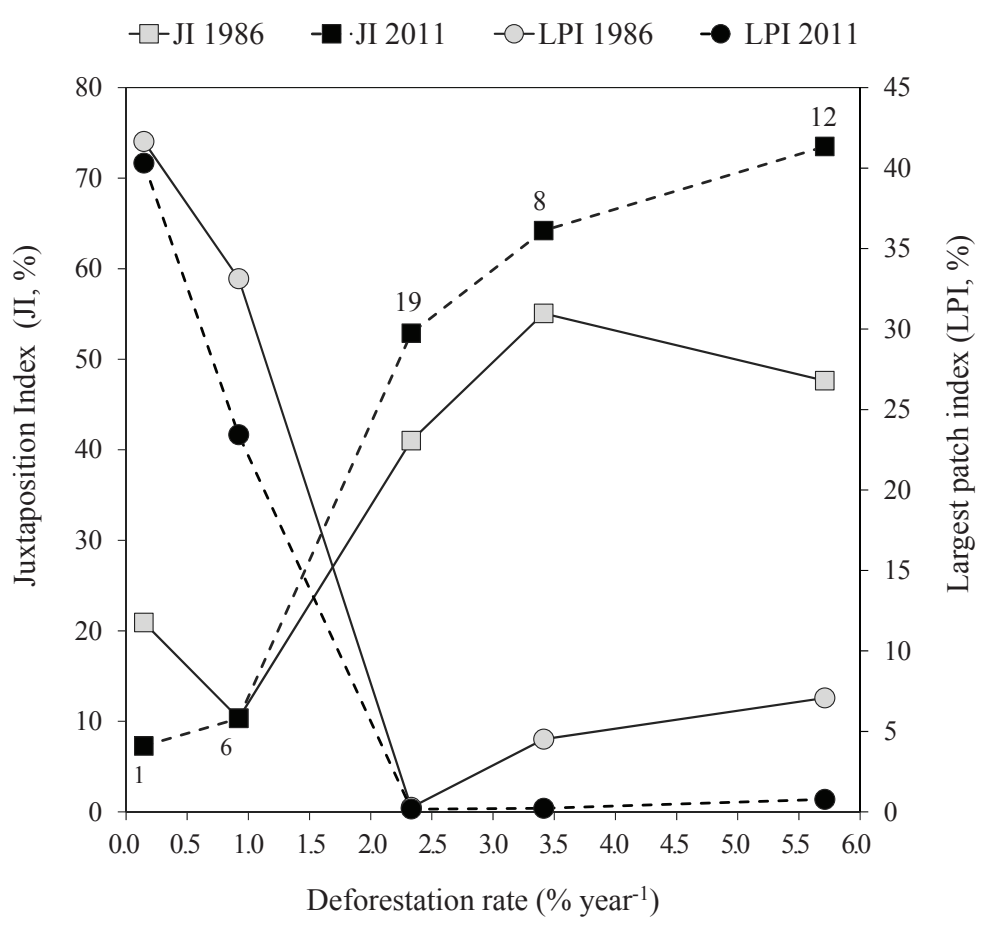

Figure 5. Landscape metrics from 1986 to 2011 for five catchments representative of the deforestation rate of the 25 study catchments. LPI: native forest largest patch index; JI: juxtaposition index. The numbers show the unprotected catchments $(8,12$, and 19$)$ and catchments located within the National System of Protected Forest Areas $(1,6)$ (see figure 3).

Métricas de paisaje calculadas para los años 1986 y 2001 en 5 cuencas representativas de las tasas de deforestación estimadas en las 25 cuencas de estudio. LPI: índice del parche más grande de bosque nativo; Ji: índice de yuxtaposición. Los números indican las cuencas emplazadas fuera $(8,12,19)$ y dentro $(1,6)$ del Sistema Nacional de Áreas Silvestres Protegidas del Estado (figura 3$)$.

land use type in most of the DWC. This pattern was associated with an increase in the degree of adjacency between patches of native forest and different anthropic land uses, mainly forest plantations.

In south-central Chile, evidence shows that after 30 years of replacing native forest by plantations of exotic species, a decline in runoff was observed along with an alteration of downstream water users (Iroumé and Palacios 2013). This may be of particular concern in drinking-water catchments where increase in evapotranspiration rates could lead to a decline in water availability for human consumption. Stand-based studies located in the coastal range in southern Chile show a higher total evapotranspiration (EVPT) in forest plantations of exotic species (45-48 \%) than that shown by native forest (30 \%) for the same study area and year (Huber and Trecaman 2004, Echeverría et al. 2007b). Higher EVPT rates (80 \%) have been reported in forest plantations located in the coastal range of southcentral Chile (Huber and Trecaman 2004), near the study area of the present study, where water scarcity is a recurrent situation (MOP 2016).

Some countries have established strict regulations to protect and conserve DWC (NHMRC 2011). For instance, Western Australia's Water Resources has developed plans and guidance that establish LUC compatibility criteria for public drinking water source areas (NSW 2010). In Chile, this kind of strategy has been rarely applied. The Nonguén National Reserve is one of the few exceptions, where water supply for human consumption has been ensured by the State (> 32,000 inhabitants). However, most of the DWC studied here are not protected by the State and are affected by the same intense dynamics of LUCC to those reported for the entire landscape (Echeverría et al. 2006). A high rate of deforestation was observed in unprotected catchments $\left(2.7 \% \pm 1.5\right.$ year $\left.^{-1}\right)$, while in the Nonguén National Reserve it was only $0.5 \% \pm 0.4$ year ${ }^{-1}$. According to our results, native forest cover in un-protected catchments is decreasing at a high rate, while there is an increment in fast-growing exotic forest plantations as well as invasive species.

Our spatio-temporal assessment of LUCC at the catchment scale reveals that there is a high degree of pressure in land condition in critical DWC. Therefore, it is urgent to develop a landscape planning strategy to ensure adequate drinking water supply for the communities living on or near these catchments. This strategy should ideally consider large-scale restoration programs to recover ecosystem processes that are essential to secure a long term and more resilient water supply for these communities. Furthermore, 
we suggest the creation of a monitoring network for these DWC that could provide robust continuous information to support scientifically based decisions for a proper management of water resources.

\section{ACKNOWLEDGEMENTS}

We are grateful to FONDECYT project 1140531. We are also grateful for the collaboration of Sergio Espinoza, Cristhian Valdebenito Olate, and Cristina Rodríguez.

\section{REFERENCES}

Alcamo J, M Flörke, M Märker. 2007. Future long-term changes in global water resources driven by socio-economic and climatic changes. Hydrological Sciences Journal 52(2): 247275. DOI: 10.1623/hysj.52.2.247

Brown A, L Zhang, A T McMahon, A Western, R Vertessy. 2005. A review of paired catchment studies for determining changes in water yield resulting from alterations in vegetation, Journal of Hydrology 310(1-4): 28-61. DOI: 10.1016/j.jhydrol.2004.12.010

Clark L. 2006. IDRISI Andes. Guide to GIS and Image Processing Clark University, 327.

CONAF, CONAMA, BIRF (Corporación Nacional Forestal, CL; Comisión Nacional del Medioambiente, CL; Banco Internacional de Reconstrucción y Fomento, US). 1999. Catastro y evaluación de los recursos vegetacionales nativos de Chile. Informe nacional con variables ambientales. Santiago, Chile.

EC (European Commissión, UE). 2012. A blueprint to safeguard Europe's water resources. Communication from the Commission (COM 2012) 673.

Echeverría C, D Coomes, J Salas, J Rey-Benayas, A Lara, A Newton. 2006. Rapid deforestation and fragmentation of Chilean Temperate Forests. Biological Conservation 130(4): 481-494. DOI: 10.1016/j.biocon.2006.01.017

Echeverría C, A Huber, F Taberlet. 2007a. Estudio comparativo de los componentes del balance hídrico en un bosque nativo y una pradera en el sur de Chile. Bosque 28(3): 271-280. DOI: $10.4067 / S 0717-92002007000300013$

Echeverría C, L Cayuela, R Manson, D Coomes, A Lara, J.M Rey Benayas, J. M, A.C Newton. 2007b. Spatial and temporal patterns of forest loss and fragmentation in Mexico and Chile. In A Newton ed., Biodiversity loss and conservation in fragmented forest landscapes: The forest of Montane Mexico and temperate South America. CABI International.
Huber A, R Trecaman. 2004. Eficiencia del uso del agua en plantaciones de Pinus radiata en Chile. Bosque 25(3): 33-43.

Huber A, A Iroume, C Mohr, C Frene. 2010. Efecto de plantaciones de Pinus radiata y Eucalyptus globulus sobre el recurso agua en la Cordillera de la Costa de la región del Biobío, Chile. Bosque 31(3): 2019-230. DOI: 10.4067/S071792002010000300006.

Iroumé A, H Palacios. 2013. Afforestation and changes in forest composition affect runoff in large river basins with pluvial regime and Mediterranean climate, Chile. Journal of Hydrology 505: 113-125. DOI: 10.1016/j.jhydrol.2013.09.031

Lara A, C Little, R Urrutia, J McPhee, C Álvarez-Garretón, C Oyarzún, D Soto, P Donoso, L Nahuelhual, M Pino, I Arismendi. 2009. Assessment of ecosystem services as an opportunity for the conservation and management of native forests in Chile. Forest Ecology and Management 2584(4): 415-424. DOI: 10.1016/j.foreco.2009.01.004

McGarigal K, S Cushman, M Neel, E Ene. 2002. FRAGSTATS: Spatial Pattern Analysis Program for Categorical Maps.

MOP (Ministerio de Obras Públicas, CL). 2016. Atlas del agua, Chile 2016. Consulted 28 jun. 2016. Available in http:// www.dga.cl/atlasdelagua/Paginas/default.aspx

MOP (Ministerio de Obras Públicas, CL). 2013. Estrategia Nacional de Recursos Hídricos. Consulted 28 jun. 2016. Available in http://www.mop.cl/Documents/ENRH_2013_OK.pdf

NHMRC, NRMMC (National Health and Medical Research Council, AU; National Resource Management Ministerial Council, AU). 2011. Australian drinking water guidelines 6. Version 3.1 Updated March 2015.

NSW (New South Wales Government, AU). 2010. 2010 Audit of the Sydney Drinking Water Catchment. Consulted 28 jun. 2016. Available in http://www.environment.nsw.gov.au/resources/water/10973AuditSDWCvol1.pdf

Nuñez D, L Nahuelhual, C Oyarzún. 2006. Forests and water: The value of native temperate forests in supplying water for human consumption. Ecological Economics 58(3): 606616. DOI: 10.1016/j.ecolecon.2005.08.010

Sun G, S McNulty, J Moore, E Cohen. 2008. Impacts of multiple stresses on water demand and supply across the Southeastern United States. Journal of the American Water Resources Association 44(6): 1441-1457. DOI: $10.1111 /$ j.17521688.2008.00250.x

UN (United Nations). 2010. The Human Right to Water and Sanitation, G.A. Res. 64/292, UN DOC. A/RES/64/292. Consulted 28 jun. 2016. Available in https://documents-dds-ny. un.org/doc/UNDOC/GEN/N09/479/35/PDF/N0947935. pdf?OpenElement 
